\title{
Domain 15 of the serine proteinase inhibitor LEKTI blocks HIV infection in vitro
}

\author{
David Palesch, ${ }^{1}$ Edina Varga,${ }^{1}$ Ute C. Marx, ${ }^{2}$ Klaus Vitzithum, ${ }^{2}$ Peter Kreutzmann, ${ }^{3}$ Wolf-Georg Forssmann, ${ }^{4}$ Jan \\ Münch, ${ }^{l}$ Hans-Jürgen Mägert ${ }^{5}$ \\ ${ }^{1}$ Institute of Molecular Virology, Ulm University Medical Center, Ulm, Germany \\ ${ }^{2}$ Lehrstuhl Biopolymere, University of Bayreuth, Bayreuth, Germany \\ ${ }^{3}$ IPF PharmaCeuticals GmbH, Hannover, Germany \\ ${ }^{4}$ Clinic of Immunology and Rheumatology, Peptide Research Group, Hannover Medical School, Hannover, Germany \\ ${ }^{5}$ Institute of Biotechnology, Anhalt University of Applied Sciences, Köthen, Germany
}

\begin{abstract}
Abstrak
Latar belakang: Inhibitor terkait inhibitor proteinase tipe limfo-epitelial Kazal (LEKTI) adalah inhibitor proteinase serin yang terdiri atas 15-domain, yang bagiannya pertama kali diisolasi dari filtrat darah manusia. LEKTI dikode oleh gen SPINK5. Berbagai penelitian telah melaporkan aktivitas anti-virus pada inhibitor proteinase serin tertentu, seperti inhibitor proteinase mukosa dan inhibitor proteinase alphal. Penelitian ini bertujuan menguji aktivitas anti-HIV dari dua domain yang mewakili inhibitor proteinase LEKTI.
\end{abstract}

Metode: LEKTI domain 6 dan 15 diproduksi secara rekombinan dalam E. coli. Untuk menguji aktivitas anti-HIV dari kedua domain tersebut, galur sel reporter P4-R5 MAGI yang mengandung gen reporter yang dapat diinduksi oleh HIV, diinfeksi dengan strain HIV CCR5 tropik, dan ditambahkan kedua domain tersebut dalam berbagai konsentrasi. Sesudah tiga hari, laju infeksi ditentukan dengan mengukur aktivitas $\beta$-galaktosidase menggunakan kit Galacto-Light Plus ${ }^{\mathrm{TM}}$ untuk uji gen reporter $\beta$-galactosidase.

Hasil: LEKTI domain 15 menghambat aktivitas gen reporter terinduksi HIV dengan nilai $I_{50}$ sekitar $29 \mu$ M, sedangkan domain 6 tidak.

Kesimpulan: LEKTI domain 15 adalah inhibitor infeksi HIV. (Med J Indones. 2013;22:131-5. doi: 10.13181/mji. v22i3.580)

\begin{abstract}
Background: Lympho-epithelial Kazal-type-related inhibitor (LEKTI) is a 15-domain serine proteinase inhibitor, parts of which have first been isolated from human blood filtrate. It is encoded by the gene SPINK5. In the past, different groups reported antiviral activities of certain serine proteinase inhibitors, such as mucus proteinase inhibitor and alpha1-proteinase inhibitor. The purpose of this study was to test two representative domains of the proteinase inhibitor LEKTI for anti-HIV activities.

Methods: LEKTI domains 6 and 15 were recombinantly produced in E.coli. To test their inhibitory activity against HIV infection, the reporter cell line P4-R5 MAGI carrying an HIV-inducible reporter gene was infected by a CCR5-tropic HIV strain in the presence of different inhibitor concentrations. After three days, infection rates were determined by quantifying $\beta$-galactosidase activities using the Galacto-Light Plus ${ }^{\mathrm{TM}}$ ß-Galactosidase Reporter Gene Assay.

Results: In contrast to LEKTI domain 6, LEKTI domain 15 suppressed HIV-induced reporter gene activities with an $\mathrm{IC}_{50}$ value of approximately $29 \mu \mathrm{M}$.

Conclusion: LEKTI domain 15 represents an inhibitor of HIV infection. (Med J Indones. 2013;22:131-5. doi: 10.13181/mji.v22i3.580)
\end{abstract}

Keywords: HIV, inhibition, LEKTI, P4-R5 MAGI

Lympho-epithelial Kazal-type-related inhibitor (LEKTI) is a 15-domain serine proteinase inhibitor, parts of which have first been isolated from human blood filtrate. It is encoded by the gene SPINK5 which, amongst others, is expressed in the skin, oral mucosa, tonsils, parathyroid gland, thymus, and lung. ${ }^{1,2}$ The primary translation product of 1064 amino acids is cleaved into single and connected functional domains at least with the involvement of the serine proteinase furin. ${ }^{3}$ LEKTI domains are capable of inhibiting the serine proteinases trypsin, plasmin, subtilisin $\mathrm{A}$, cathepsin $\mathrm{G}$, and human neutrophil elastase. ${ }^{4}$ However, as shown by various groups, the main biological function of LEKTI might be the regulation of kallikrein-related endopeptidases, which are involved in skin desquamation and inflammation, such as KLK5, KLK7 and KLK14. ${ }^{5-7}$ Indeed, SPINK5 mutations resulting in impaired LEKTI functions may lead to the development of a severe congenital skin disease, i.e. Comèl-Netherton syndrome. ${ }^{8}$ Moreover, they are associated with disorders of the allergic triad including atopic dermatitis and asthma. ${ }^{9-11}$ In the past, different groups reported antiviral activities of certain serine proteinase inhibitors, such as mucus proteinase inhibitor and alpha1-proteinase inhibitor. ${ }^{12,13}$ Therefore, 
we decided to check for comparable activities of selected LEKTI domains. In this work, we show that LEKTI domain 15 is a potent inhibitor of HIV infection by utilizing the human reporter cell line P4-R5 MAGI.

\section{METHODS}

This study was performed in the Institute of Molecular Virology, Ulm University Medical Center, Ulm, Germany from 2009 - 2013.

\section{Recombinant production of LEKTI domains}

LEKTI domains 6 and 15 were recombinantly produced in E. coli and purified as described. ${ }^{14,15}$ Briefly, bacteria were grown in LB medium and the expression of the peptides was induced by addition of 1 mM IPTG (isopropyl-beta-D-thiogalactopyranoside). Purification of the peptides from soluble cell extracts was followed by routinely performed peptide analysis such as N-terminal amino acid sequencing and mass spectrometry.

\section{Sequence comparison of LEKTI domains}

Amino acid sequence comparison of LEKTI domains 6 and 15 was performed by means of the LALIGN tool (http://www.ebi.ac.uk/Tools/psa/lalign/).

\section{HIV infection assay}

P4-R5 MAGI ${ }^{16}$ cells (obtained through the NIH AIDS Reagent Program, Division of AIDS, NIAID, NIH: from Dr. Nathaniel Landau) and 293T cells were maintained in Dulbecco's modified Eagle's medium containing $10 \%$ heat-inactivated fetal bovine serum. Virus stocks were produced by transient transfection of $293 \mathrm{~T}$ cells with pBRHIV-1-NL4.3 proviral DNA using calcium phosphate precipitation. ${ }^{17}$ After two days, cellular supernatants containing viral particles were harvested, filtrated to remove cellular debris, and assayed by p24 ELISA (provided by the AIDS \& Cancer Virus Program; NCI, Frederick).
Five thousand P4-R5 MAGI cells were seeded in 96-well microtiter plates. The following day, serial dilutions of peptides were added to cells and infected with CCR5-tropic HIV-1 NL4-3 92TH014.2 containing $1 \mathrm{ng}$ p24 antigen in a total cell culture volume of 200 $\mu \mathrm{L}$. After three days, infection rates were determined by quantifying $ß$-galactosidase activities using the Galacto-Light Plus ${ }^{\mathrm{TM}}$ ß-Galactosidase Reporter Gene Assay System (Life Technologies, Carlsbad) according to the manufacturer's instructions and an Orion Microplate Luminometer (Berthold Detection Systems, Pforzheim).

\section{RESULTS}

Amino acid sequence comparison of LEKTI domains 6 and 15, which was performed by the LALIGN tool, showed that both domains share only $31.6 \%$ sequence identity (Figure 1).

To test the inhibitory potential of LEKTI domains on HIV infection, we incubated the HIV-1 reporter cell line P4-R5 MAGI with the two LEKTI domains and subsequently infected the cells with HIV-1 NL43. As depicted in Figure 2, P4-R5 MAGI cells are stably transfected with an LTR-lacZ (lacZ encodes the reporter enzyme $\beta$-galactosidase) construct. Upon infection, the virally encoded transactivator protein Tat is synthesized and subsequently activates genes under the control of the LTR promoter, including the the lacZ gene. ß-galactosidase activities were determined three days later using a luminescencebased assay.

As shown in Figure 3, we found that LEKTI domain 15 dose-dependently blocked reporter gene activities with a $50 \%$ inhibitory concentration $\left(\mathrm{IC}_{50}\right)$ of $28.8 \pm$ $2.2 \mu \mathrm{M}$. Further, cytotoxic activity of this peptide was not detectable. In contrast, LEKTI domain 6 did not show any anti-HIV activity in concentrations up to $100 \mu \mathrm{M}$ (data not shown). These data demonstrate that LEKTI domain 15 is an inhibitor of HIV-1 infection.

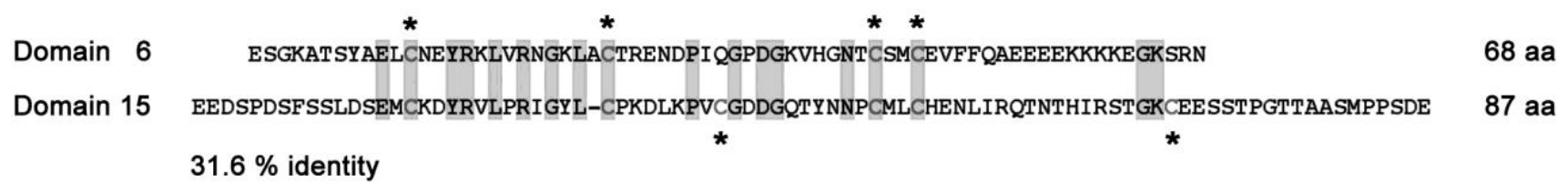

Figure 1. Sequence comparison of LEKTI domains 6 and 15. LEKTI domain 6 almost exactly represents the consensus sequence of all LEKTI domains exhibiting two disulfide bonds. Like the original Kazal-type inhibitor PSTI, LEKTI domain 15 exhibits three disulfide bonds. Asterisks above the sequences indicate the four cysteine residues conserved in all of the 15 LEKTI domains. Asterisks below the sequences indicate the two additional cysteine residues, which are typical for Kazal-type inhibitors, as represented in LEKTI domains 2 and 15. According to analysis by the LALIGN tool, both domains share 31.6\% sequence identity. Abbreviations: $a a=$ amino acids. 


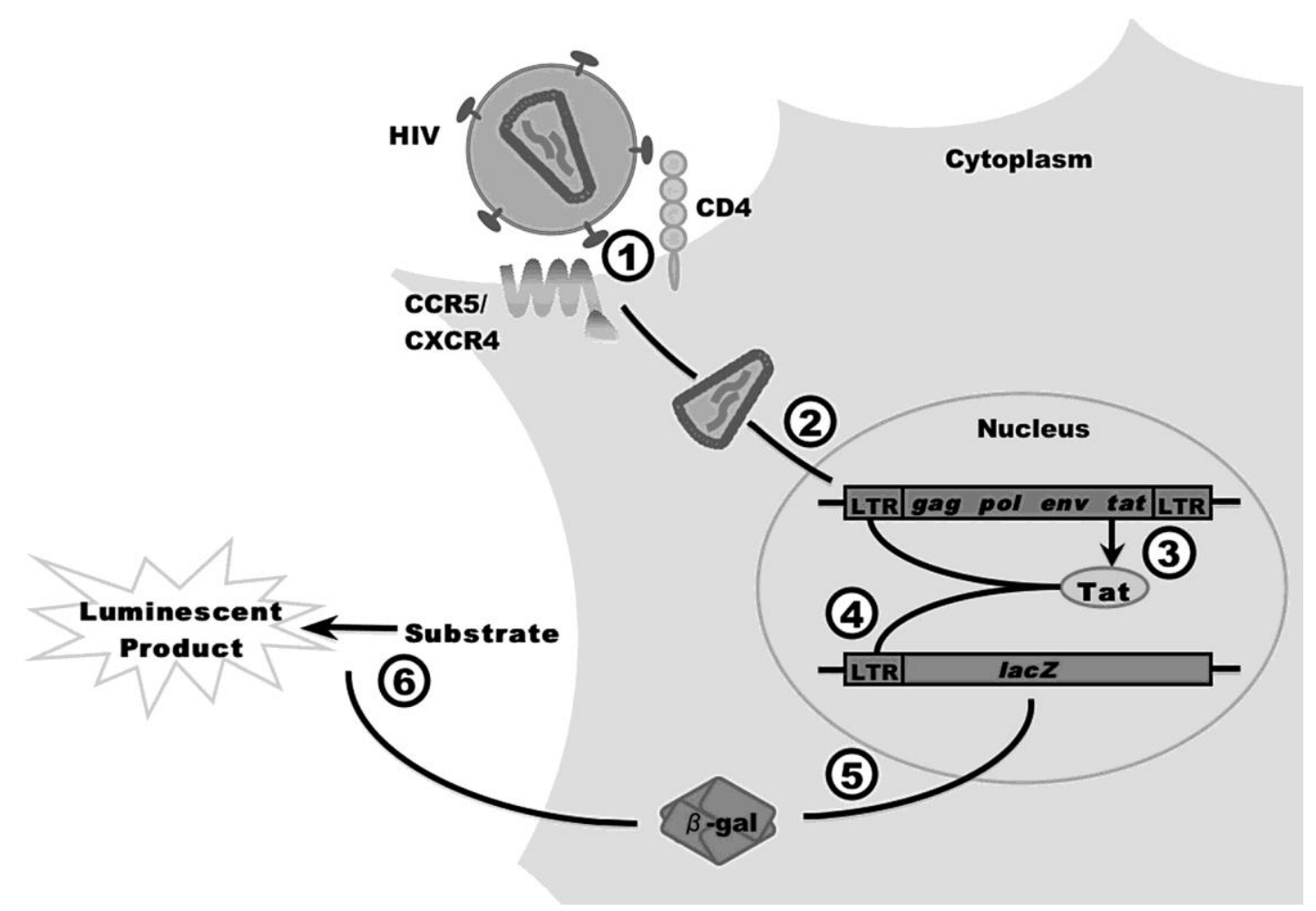

Figure 2. Schematic drawing of the HIV-1 inhibition assay in P4-R5 MAGI cells

1) Entry: HIV-1 particles interact with the primary receptor CD4 and one of the two coreceptors CXCR4 or CCR5, which results in fusion of the viral membrane with the cellular membrane. 2) Reverse transcription and integration: After the uncoating of the incoming viral particle, the viral RNA genome is reverse transcribed into double-stranded DNA and integrated into the host cell genome. 3) Viral gene expression: Like cellular DNA, the proviral HIV DNA is expressed. Besides genes encoding for structural proteins (gag), enzymes (pol) and the glycoprotein (env), HIV also encodes the transactivator protein Tat. 4) Transactivation: Tat activates viral gene expression via binding to the viral promoter region, the LTR. 5) Reporter gene expression: P4-R5 MAGI cells are stably transfected with an LTR-lacZ construct. Tat transactivates expression of the lac Z gene, resulting in the generation of $\beta$-galactosidase molecules. 6) Reporter enzyme detection: $\beta$-galactosidase activity is determined in cellular lysates by adding a substrate, which emits light (luminescence) when being hydrolyzed by the enzyme.

\section{DISCUSSION}

Several groups have published that certain serine proteinase inhibitors including secretory leukocyte proteinase inhibitor (SLPI), alpha1-proteinase inhibitor and VIRIP, a 20-amino acid fragment of the latter protein, inhibit HIV-1 infection. ${ }^{12,13,18}$ Thus, we decided to examine whether recombinant LEKTI domains are also capable of inhibiting HIV entry. We selected LEKTI domains 6 and 15 because LEKTI domain 6 almost exactly represents the consensus sequence of all 15 LEKTI domains. ${ }^{1}$ On the other hand, like domain 2, LEKTI domain 15 differs from the other 13 LEKTI domains, as it exhibits three instead of two disulfide bonds and is thus more closely related to the pancreatic secretory trypsin inhibitor (PSTI) - the original Kazaltype inhibitor. ${ }^{1}$

P4-R5 MAGI cells were used as a reporter cell line for HIV infection. It represents a transfected HeLa-derived cell line stably expressing the HIV receptor CD4, as well as both co-receptors CXCR4 and CCR5. ${ }^{16}$

The results presented in this paper show an inhibitory activity of LEKTI domain 15, but not domain 6 on infection of P4-R5 MAGI cells by CCR5-tropic HIV-1. The mechanism by which LEKTI domain 15 is blocking viral infection needs to be determined. Since LEKTI exerts proteinase inhibitor activity, it is tempting to speculate that it might block HIV-1 replication by a mode of action similar to clinically approved proteinase inhibitors. However, a possible inhibition of the viral proteinase cannot be analyzed in the P4-R5 MAGI cells because this reporter cell line only allows analysis of compounds which target early steps in the viral life cycle. These include all processes taking place prior to the expression of the viral transactivator protein Tat. Later events such as proteinase-mediated maturation of viral particles, which occur just upon virion budding, cannot be detected. Thus, the observed inhibition of 


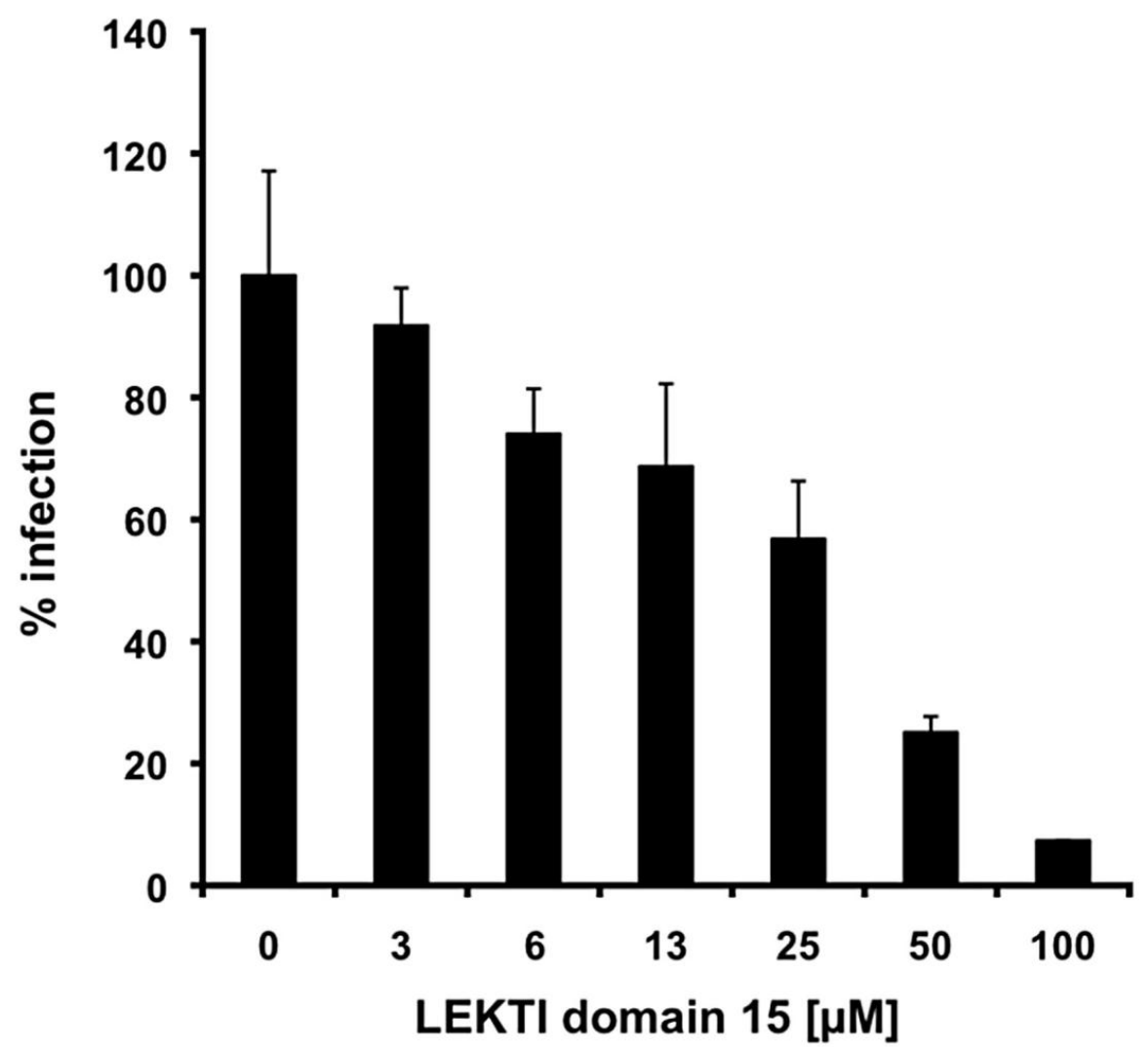

Figure 3. LEKTI domain 15 blocks HIV-1 infection.

Values shown represent average values ( \pm standard deviation) from two experiments, each performed in triplicate relative to control infections without the presence of any LEKTI domains ( $=100 \%)$

HIV-1 infection by LEKTI domain 15 in the P4-R5MAGI system suggests that this fragment either blocks viral entry at the cell surface, or subsequent intracellular events such as uncoating of the viral RNA, its reverse transcription into DNA, the integration of the provirus into the cellular genome, or the expression of viral genes. Since our previous results revealed that LEKTI cannot be internalized by cells, it is likely that LEKTI domain 15 interferes with HIV-1 entry.

Interestingly, we have previously identified another fragment of a proteinase inhibitor, which blocks HIV1 infection by preventing its fusion with the cellular membrane. This peptide, termed VIRIP (VIRus Inhibitory Peptide), represents a 20-amino-acid fragment, which was derived from alpha1-proteinase inhibitor and was isolated from human blood filtrate. ${ }^{18}$ VIRIP inhibits HIV-1 entry by interacting with the fusion peptide in the viral glycoprotein gp41. The fusion peptide mediates the first tight contact between the viral and the cellular membranes. VIRIP prevents the fusion peptide form being inserted into the membrane and hence blocks HIV-1 infection. It would be interesting to find out whether LEKTI domain 15 has a similar mode of action.
The reported $\mathrm{IC}_{50}$ value of VIRIP is $26 \mu \mathrm{M},{ }^{18}$ which is in the range of the $\mathrm{IC}_{50}$ value of LEKTI domain 15 $(29 \mu \mathrm{M})$. In the case of VIRIP, a structure-activity relationship study allowed the antiviral activity to increase by two orders of magnitude. ${ }^{18}$ Thus, it appears to be promising to initiate a similar approach to detect amino acids that are essential for the HIV inhibitory activity of LEKTI domain 15 (e.g. via alanine scan), to subsequently generate sequence variations by PCR-based site-directed mutation and/or randomly by inaccurate PCR, and to identify whether those variations exhibit highly increased inhibitory activities.

In conclusion, we were able to demonstrate the inhibitory potential of LEKTI domain 15 on infection of a reporter cell line by CCR 5-tropic HIV-1 NL4-3. Further investigations are now required to determine the mechanism of inhibition, to generate variants with increased activities and to analyze the suitability of LEKTI domain 15 and/or its variants as anti-HIV drugs in vivo.

\section{REFERENCES}

1. Mägert HJ, Kreutzmann $P$, Ständker L, Walden $M$, Drögemüller K, Forssmann WG. LEKTI: a multidomain 
serine proteinase inhibitor with pathophysiological relevance. Int J Biochem Cell Biol. 2002;34(6):573-6.

2. Mägert HJ, Kreutzmann P, Drögemüller K, et al. The 15-domain serine proteinase inhibitor LEKTI: biochemical properties, genomic organization, and pathophysiological role. Eur J Med Res. 2002;7(2):49-56.

3. Bitoun E, Micheloni A, Lamant L, et al. LEKTI proteolytic processing in human primary keratinocytes, tissue distribution and defective expression in Netherton syndrome. Hum Mol Genet. 2003;12(19):2417-30.

4. Mitsudo K, Jayakumar A, Henderson Y, et al. Inhibition of serine proteinases plasmin, trypsin, subtilisin A, cathepsin $\mathrm{G}$, and elastase by LEKTI: a kinetic analysis. Biochemistry 2003;42(13):3874-81.

5. Egelrud T, Brattsand M, Kreutzmann P, et al. hK5 and hK7, two serine proteinases abundant in human skin, are inhibited by LEKTI domain 6. Br J Dermatol. 2005;153(6):1200-3.

6. Schechter NM, Choi EJ, Wang ZM, et al. Inhibition of human kallikreins 5 and 7 by the serine protease inhibitor lympho-epithelial Kazal-type inhibitor (LEKTI). Biol Chem. 2005;386(11):1173-84.

7. Deraison C, Bonnart C, Lopez F, et al. LEKTI fragments specifically inhibit KLK5, KLK7, and KLK14 and control desquamation through a $\mathrm{pH}$-dependent interaction. Mol Biol Cell. 2007;18(9):3607-19.

8. Chavanas S, Bodemer C, Rochat A, et al. Mutations in SPINK5, encoding a serine protease inhibitor, cause Netherton syndrome. Nat Genet. 2000;25(2):141-2.

9. Walley AJ, Chavanas S, Moffatt MF, et al. Gene polymorphism in Netherton and common atopic disease. Nat Genet. 2001;29(2):175-8.

10. Kato A, Fukai K, Oiso N, Hosomi N, Murakami T, Ishii M. Association of SPINK5 gene polymorphisms with atopic dermatitis in the Japanese population. Br J Dermatol. 2003;148(4):665-9.

11. Liu Q, Xia Y, Zhang W, et al. A functional polymorphism in the SPINK5 gene is associated with asthma in a Chinese Han Population. BMC Med Genet. 2009;10:59.

12. McNeely TB, Shugars DC, Rosendahl M, Tucker C, Eisenberg SP, Wahl SM. Inhibition of human immunodeficiency virus type 1 infectivity by secretory leukocyte protease inhibitor occurs prior to viral reverse transcription. Blood 1997;90(3):1141-9.

13. Shapiro L, Pott GB, Ralston AH. Alpha-1-antitrypsin inhibits human immunodeficiency virus type 1. FASEB J. 2001;15(1):115-22.

14. Kreutzmann P, Schulz A, Ständker L, Forssmann WG, Mägert HJ. Recombinant production, purification and biochemical characterization of domain 6 of LEKTI: a temporary Kazal-type-related serine proteinase inhibitor. J Chromatogr B Analyt Technol Biomed Life Sci. 2004;803(1):75-81.

15. Vitzithum K, Lauber T, Kreutzmann P, et al. LEKTI domain 15 is a functional Kazal-type proteinase inhibitor. Protein Expr Purif. 2008;57(1):45-56.

16. Wei X, Decker JM, Liu H, et al. Emergence of resistant human immunodeficiency virus type 1 in patients receiving fusion inhibitor (T-20) monotherapy. Antimicrob Agents Chemother 2002;46(6): 1896-905.

17. Hiebenthal-Millow K, Kirchhoff F. The most frequent naturally occurring length polymorphism in the HIV1 LTR has little effect on proviral transcription and viral replication. Virology 2002;292(1):169-75.

18. Münch J, Ständker L, Adermann K, et al. Discovery and optimization of a natural HIV-1 entry inhibitor targeting the gp41 fusion peptide. Cell 2007;129(2):263-75. 